\title{
A new and openly accessible database of tests on piles driven in sands
}

\author{
Z. X. YANG*, R. J. JARDINE†, W. B. GUO* and F. CHOW†
}

\begin{abstract}
This paper reviews the critical need to develop better load test databases for piles driven in sand before reporting on the significantly augmented, openly accessible, Zhejiang University/Imperial College London (ZJU-ICL) database. Key quality parameters, the population of current entries and the reporting format are described before offering preliminary results obtained from comparisons between axial capacities calculated by various predictive approaches and site measurements. The results confirm that the offshore industry-standard 'Main Text' American Petroleum Institute RP2GEO procedures are less reliable and have larger coefficients of variation than alternative cone penetration test (CPT) methods, among which the ICP (Imperial College piles) and UWA (University of Western Australia) procedures appear to give the least bias and scatter. It is also shown that the 'simplified' ICP variant proposed by some practitioners is over-conservative and that its use could be discontinued. The new pile capacity and stiffness database offers broad scope for evaluating potential prediction biases relating to a wide range of soil and pile parameters. The submission of further high-quality tests for inclusion in regularly updated versions of the ZJU-ICL database is encouraged.
\end{abstract}

KEYWORDS: design; full-scale tests; piles; sands

ICE Publishing: all rights reserved

\section{INTRODUCTION}

Predicting the behaviour of piles driven in sand is an important industrial issue, particularly in offshore engineering where it can affect the practicality and economics of major oil, gas and wind energy projects. Axial capacity predictions are crucial to many applications, especially those involving offshore tension leg, tripod or jacket structures (e.g. Overy, 2007; Merritt et al., 2012; Jardine, 2013). Foundation stiffness can also be important to both structural fatigue life and wind turbine operations. Database studies in which field measurements are compared with results from routine predictive calculations show that the latter's accuracy and reliability are often far lower than practitioners appreciate. For example, Briaud \& Tucker (1988) demonstrated that conventional axial capacity calculations $\left(Q_{\mathrm{c}}\right)$ show considerable bias and scatter when predictions are compared to the capacities measured in careful field tests $\left(Q_{\mathrm{m}}\right)$.

Fundamental research with field Imperial College piles (ICPs) equipped with high-quality surface stress transducers carried out by Lehane et al. (1993) and Chow (1997) revealed that the routine methods fail to capture key aspects of the stress regime that develops around pile tips and shafts during penetration in sand. The tip stresses were found to correlate directly with local cone penetration test $(\mathrm{CPT})$ resistances $\left(q_{\mathrm{c}}\right)$, as did the radial stresses $\left(\sigma_{\mathrm{rc}}^{\prime}\right)$ set up on the pile shafts. The latter also reduced systematically, at any given depth $(z)$ below ground level, as the pile tip

Manuscript received 15 September 2014; first decision 3 October 2014; accepted 4 December 2014.

Published online at www.geotechniqueletters.com on 25 January 2015.

*Department of Civil Engineering, Zhejiang University, Hangzhou, China

†Department of Civil and Environmental Engineering, Imperial College, London, UK

tFormerly of Imperial College, London, UK advanced and the relative height above the tip $\left(h=z-z_{\text {tip }}\right)$ increased. A weak dependence on the free-field vertical effective stress $\left(\sigma_{\mathrm{v} 0}^{\prime}\right)$ was also identified. Jardine et al. (2005) proposed functions that related $\sigma_{\mathrm{rc}}^{\prime}$ to $q_{\mathrm{c}}, \sigma_{\mathrm{v} 0}^{\prime}$ and $h / R$ for closed-ended piles that only required slight modification (substituting an equivalent radius $R^{*}$ ) to be used for openended piles. The ICP experiments also showed that shaft loading generated local radial stress changes that varied with pile diameter and loading sense, while local shaft failure developed once a critical state interface shear angle was developed that could be predicted from laboratory tests and correlated with grain size and pile shaft roughness. Simple expressions were developed that captured the above shaft capacity phenomena and also pile end bearing capacity. Subsequent research has considered additional factors, including

- the influence of load cycles imposed during installation (White \& Lehane, 2004; Jardine et al., 2013a)

- time effects (Jardine et al., 2006; Gavin et al., 2013; Karlsrud et al., 2014)

- how particle breakage under the tip and surface abrasion affect the stresses and the development of a well-defined interface shear zone (Yang et al., 2010)

- the stress regime developed in the surrounding soil mass (Jardine et al., 2009, 2013b)

- the influence of cyclic loading (Tsuha et al., 2012).

Yang et al. (2014) and Zhang et al. (2014) have gone on to relate stress measurements from experimental investigations and numerical analyses by other workers.

New practical design tools were proposed from the work of Lehane et al. (1993) and Chow (1997), which evolved into the updated Imperial College (ICP-05) method detailed by Jardine et al. (2005). Other groups developed alternative approaches that recognised similar features of physical behaviour through alternative formulations. These include Fugro-05 (Kolk et al., 2005), Norwegian 
Geotechnical Institute NGI-05 (Clausen et al., 2005) and University of Western Australia UWA-05 (Lehane et al., 2005). Rigorous database studies have become key tools to assess the potential efficacy of these new design procedures. Lehane \& Jardine (1994), Chow (1997), Clausen et al. (2005), Jardine et al. (2005), Kolk et al. (2005) and Schneider et al. (2008) all assembled databases to test their new CPT-based design procedures in comparison with the offshore industry-standard 'Main Text' American Petroleum Institute RP2GEO (API, 2014) approach and its forebears. They found that the Main Text approach was subject to surprisingly high overall coefficients of variance (CoVs) in $Q_{\mathrm{c}} / Q_{\mathrm{m}}$ (up to $0 \cdot 88$ ) when predicting compression capacity in sand and that the new procedures led to lower CoVs and less bias with respect to pile geometry (diameter $(D)$ and $L / D$ ratio $(L=$ embedded length)), loading sense (tension or compression) and sand relative density $\left(D_{\mathrm{r}}\right)$. Williams et al. (1997), Jardine et al. (2005) and Overy (2007) reported case histories where the Main Text approach gave $Q_{\mathrm{c}} / Q_{\mathrm{m}}$ values ranging from $0 \cdot 4$ to $2 \cdot 9$.

The current RP2GEO (API, 2014) acknowledges the limitations of its Main Text approach and the potential advantages of the new CPT methods. But it also notes industry's lack of experience with the new methods. Practitioners are uncertain as to which, if any, of the four methods they should adopt for routine application, and their assessments are made difficult by the general limitations of pile test databases and in particular a lack of high-quality tests on large piles in silica sands at sites that have been characterised to a high standard.

The most comprehensive sets appear to be those assembled by Chow (1997) and later updated by Jardine et al. (2005), termed here the ICP database, and that published by Schneider et al. (2008), which is here referred to as the UWA database. Taken together, these include over 100 different piles driven in silica sand and tested to failure. However, only 11 piles (from just three sites) were open-ended, had $D \geqslant 600 \mathrm{~mm}$ and full CPT profiles. Further tests are required to augment this sparse dataset, obtain information from a wider range of international sites and gain further insight into uncertain factors such as the effects of layering on base resistance $(\mathrm{Xu}, 2006)$ and the effects of pile age on capacity (Jardine et al., 2006; Gavin et al., 2013; Karlsrud et al., 2014).

The Zhejiang University/Imperial College London (ZJUICL) database project was initiated in 2011 to augment the internationally available open database of high-quality pile load tests and so allow design pile capacity and stiffness design methods to be tested and improved. This paper outlines how the database may be accessed, used and added to by other workers. It also describes the methodology adopted, the population of current entries and the digital reporting format, before describing some preliminary results obtained in comparisons of axial capacities calculated by various approaches and site measurements.

\section{DATABASES FOR PILES DRIVEN IN SANDS}

The starting point for the new ZJU-ICL was the ICP and UWA databases. The ICP set reported by Jardine et al. (2005) added a significant number of new case histories to those assembled by Lehane \& Jardine (1994) and Chow (1997), and offered a total of 83 tests in sand. Schneider et al. (2008) augmented the ICP tests, adding 26 previously unrecognised entries. The UWA team also applied further quality filters, such as excluding any tests without full CPT profiles.

The ZJU-ICL database applies similar, but marginally more stringent, criteria as follows.

- All entries must be accompanied by an adequate site investigation, including a complete CPT profile from a close location, soil descriptions, information on groundwater levels and sand grain size distribution. Ideally, good measurements of in situ density and interface shearing angles should also be available. Only silica sand sites may be included.

- Complete information on driving method, pile embedment, diameter, tip end conditions, wall thickness and material must be provided. Ideally, the pile driving records and pile age after driving should also be available. The database is then divided into a main set with pile ages of $10-100 \mathrm{~d}$, and a sub-set of tests conducted at both earlier and later ages. Tests for which

Table 1. General characteristics of the ICP, UWA and ZJU-ICL databases (pile age $=10-100 \mathrm{~d}$ )

\begin{tabular}{|c|c|c|c|}
\hline & ICP database (2005) & UWA database & Total ZJU-ICL database \\
\hline Total number of tests & $64+19=83$ & 77 & 115 \\
\hline New tests & 83 & 26 & 47 \\
\hline Accepted new tests & 37 & 41 (36 from ICP, plus 5 from UWA) & $\begin{array}{l}80 \text { ( } 37 \text { from ICP, } 5 \text { UWA and } 38 \\
\text { ZJU-ICL) }\end{array}$ \\
\hline Pile types & $\begin{array}{l}\text { Mainly driven, but with one } \\
\text { vibro-driven and eight jacked }\end{array}$ & Only driven piles & Only driven piles \\
\hline Pile shape & Circular, square and octagonal & Circular, square and octagonal & Circular, square and octagonal \\
\hline Pile diameter: $\mathrm{mm}$ & $200-2000$ & $200-2000$ & $200-2000$ \\
\hline Pile length: m & $5 \cdot 3-46 \cdot 7$ & $5 \cdot 3-79 \cdot 1$ & $5 \cdot 3-79 \cdot 1$ \\
\hline Soil description & $\begin{array}{l}\text { Mainly siliceous sands, carbonate } \\
\text { contents less than } 15 \% \text {, shaft } \\
\text { length in clay }<40 \%\end{array}$ & $\begin{array}{l}\text { Pile tips bearing siliceous sand and } \\
\text { siliceous sand contributes }>50 \% \text { of } \\
\text { shaft capacity }\end{array}$ & $\begin{array}{l}\text { Pile tips bearing a siliceous sand } \\
\text { and siliceous sand contributes } \\
>65 \% \text { of shaft capacity }\end{array}$ \\
\hline Load test & $\begin{array}{l}\text { Static; base and shaft capacity } \\
\text { separated individually }\end{array}$ & Static & Static \\
\hline Failure criterion & $\begin{array}{l}\text { If no clear peak indicated in } \\
\text { compression, pile head displace- } \\
\text { ment of } 0 \cdot 1 D \text { (outer diameter); } \\
\text { failure in tension usually well } \\
\text { defined }\end{array}$ & $\begin{array}{l}\text { If no clear peak indicated in } \\
\text { compression, pile head displace- } \\
\text { ment of } 0 \cdot 1 D \text { (outer diameter); } \\
\text { tension defined as maximum uplift } \\
\text { load minus pile weight }\end{array}$ & $\begin{array}{l}\text { If no clear peak indicated in } \\
\text { compression, pile head displace- } \\
\text { ment of } 0 \cdot 1 D \text { (outer diameter); } \\
\text { tension defined as maximum } \\
\text { uplift load minus pile weight }\end{array}$ \\
\hline Age on testing & $\begin{array}{l}\text { Pile tests conducted } 0 \cdot 5 \text { to } 200 \mathrm{~d} \\
\text { after driving. Average age after } \\
\text { driving was } 34 \mathrm{~d} \text {. Time details } \\
\text { reported in } 74 \% \text { of case records }\end{array}$ & $\begin{array}{l}\text { Time between driving and load } \\
\text { testing typically } 0 \cdot 5 \text { to } 200 \mathrm{~d} \\
\text { (average } 24 \mathrm{~d} \text { ). Time details } \\
\text { reported in } 77 \% \text { of the case records }\end{array}$ & $\begin{array}{l}\text { Pile tests conducted } 11 \text { to } 89 \mathrm{~d} \text {, } \\
\text { with an average of } 35 \mathrm{~d} \text { after } \\
\text { driving. Time details reported in } \\
50 \% \text { of the case records }\end{array}$ \\
\hline
\end{tabular}




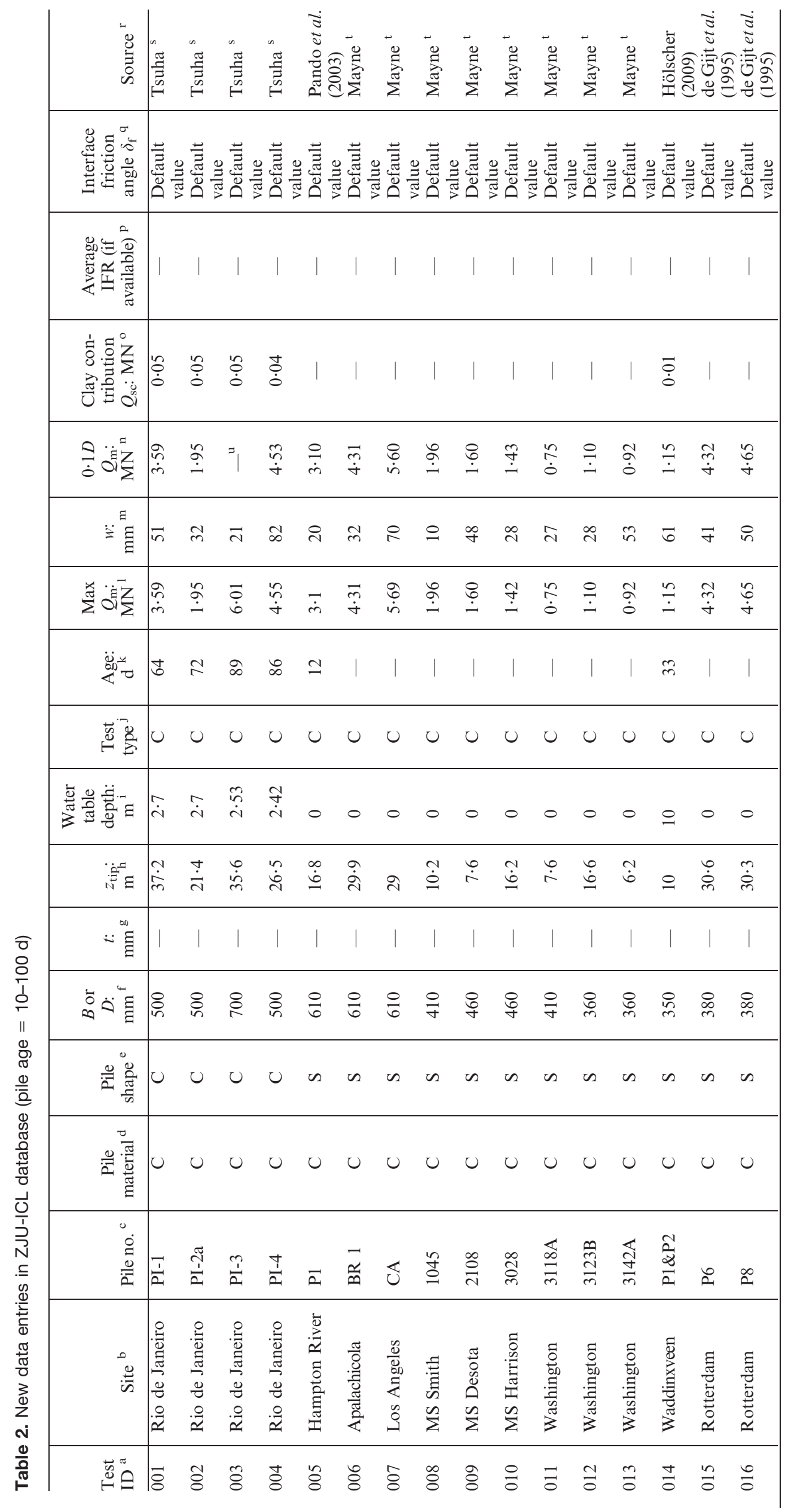




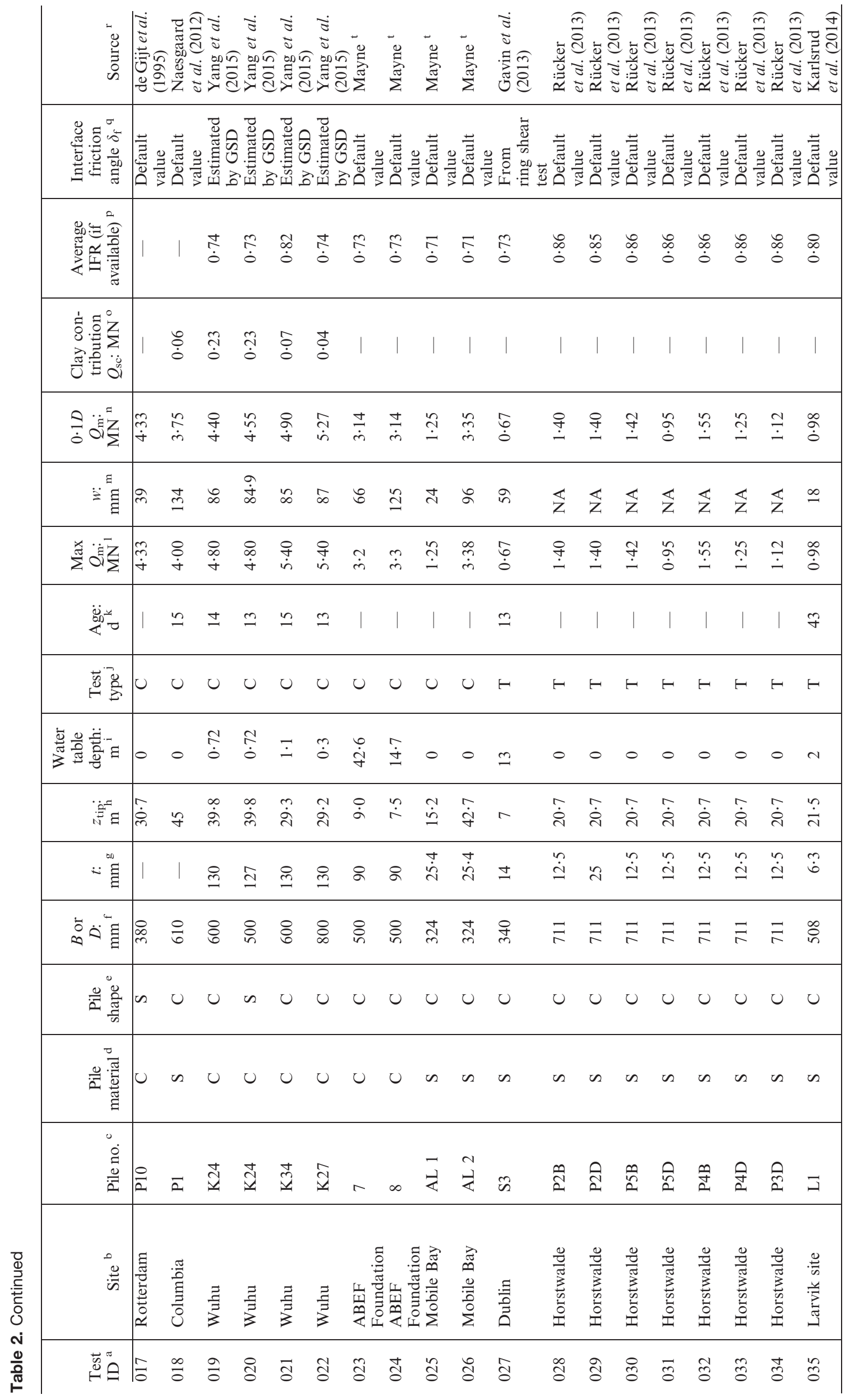




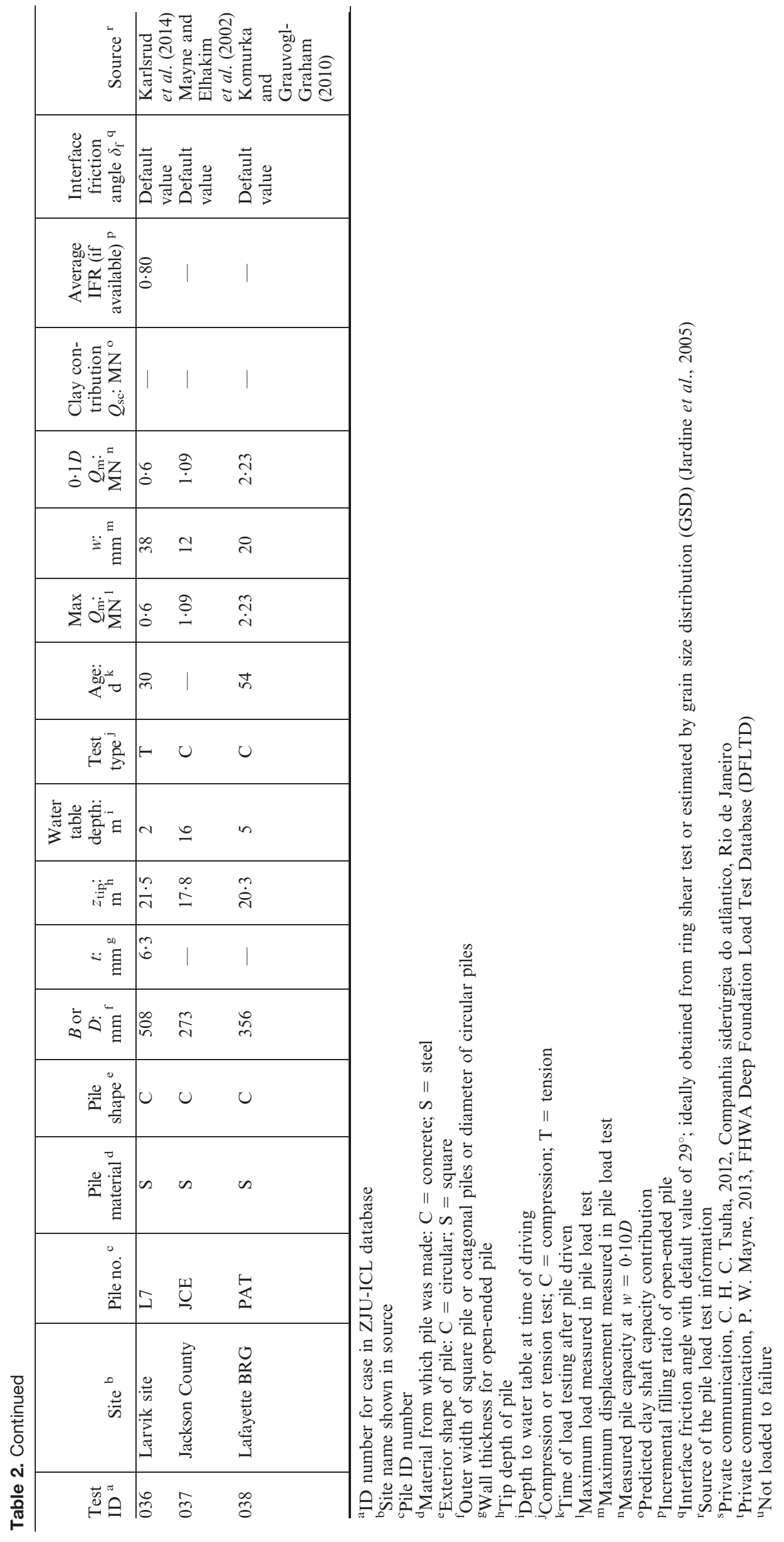


Table 3. Summary of ZJU-ICL database (pile age $=10-100 \mathrm{~d}$ )

\begin{tabular}{l|c|cc}
\hline & Closed & Open & All \\
\hline Number of piles & 48 & 32 & 80 \\
Steel & 18 & 26 & 44 \\
Concrete & 30 & 6 & 36 \\
Tension tests & 8 & 16 & 24 \\
Compression tests & 40 & 16 & 56 \\
Average length $L: \mathrm{m}$ & $18 \cdot 9$ & $26 \cdot 0$ & $21 \cdot 8$ \\
Range of $L: \mathrm{m}$ & $6 \cdot 18-45 \cdot 00$ & $5 \cdot 3-79 \cdot 1$ & $5 \cdot 3-79 \cdot 1$ \\
Average diameter $D: \mathrm{m}$ & $0 \cdot 422$ & $0 \cdot 324-2 \cdot 000$ & $0 \cdot 520$ \\
Range of $D: \mathrm{m}$ & $0 \cdot 2-0 \cdot 7$ & 61 & $0 \cdot 2-2 \cdot 0$ \\
Average density $D_{\mathrm{r}}: \%$ & 54 & $30-87$ & 57 \\
Range of $D_{\mathrm{r}}: \%$ & $31-89$ & 28 & $30-89$ \\
Average test time after instal- & 43 & & 35 \\
lation: $\mathrm{d}$ & & & \\
\hline
\end{tabular}

the age is uncertain are assumed to fall in the usual range of $10-100 \mathrm{~d}$.

- All entries must include records from high-quality (ideally load-controlled) first-time axial tests to failure, including load-displacement curves that continue until either peak loads or axial displacements have developed. Tests equipped with strain gauges and tension tests to failure are particularly valuable for isolating the shaftto-base capacity splits from compression tests.

Applying the above filters to the baseline dataset led to 37 entries being adopted from the ICP database along with five additional cases from the UWA set. To date, the ZJUICL team has also assembled 38 further new test entries from the literature, their own projects (including four openended concrete piles with outer diameter ranging from 600 to $800 \mathrm{~mm}$ (Yang et al., 2015)) and through acknowledged communication with other research groups worldwide. The new cases contribute a $90 \%$ increase in the total population of tests that meet the criteria outlined above. Table 1 summarises the characteristics of the ICP, UWA and ZJUICL databases, while Tables 2 and 3 give details of the new entries and characteristics of the combined ZJU-ICL database.

Ideally, test piles should be instrumented to allow the shaft load distributions to be defined and the base capacities isolated in compression tests. A good spread of tension tests is also desirable. All of the ICP database entries adopted involved either strain gauged piles or tension tests. However, only three of the five new entries from the UWA database and 14 of the 38 new ZJU-ICL cases (including tension tests) allow shaft and base capacities to be separated. The new database will be made available from a website hosted by Zhejiang University (http://mypage.zju.edu.cn/en/zxyang/682156.html) that is under construction and will be appearing in March 2015, with a hard copy version being published simultaneously by Zhejiang University and Elsevier Joint Press. Each case will be entered in the format similar to that adopted by Niazi (2014). An example entry from the authors' research at the Wuhu Yangtze River Bridge site in China (Yang et al., 2015) is given in the Appendix.

Figure 1 illustrates the geographical distribution of the new combined dataset, which increases the number of countries considered from 10 to 13 . The ZJU-ICL team will update the database periodically and the authors welcome the submission of any new test entries that meet the above criteria and data quality levels illustrated in the Appendix. All such entries will be acknowledged fully and will increase the value of this inclusive and freely available international research resource.

\section{PRELIMINARY FINDINGS}

The remainder of this paper outlines some preliminary findings from the database. Far more detailed studies

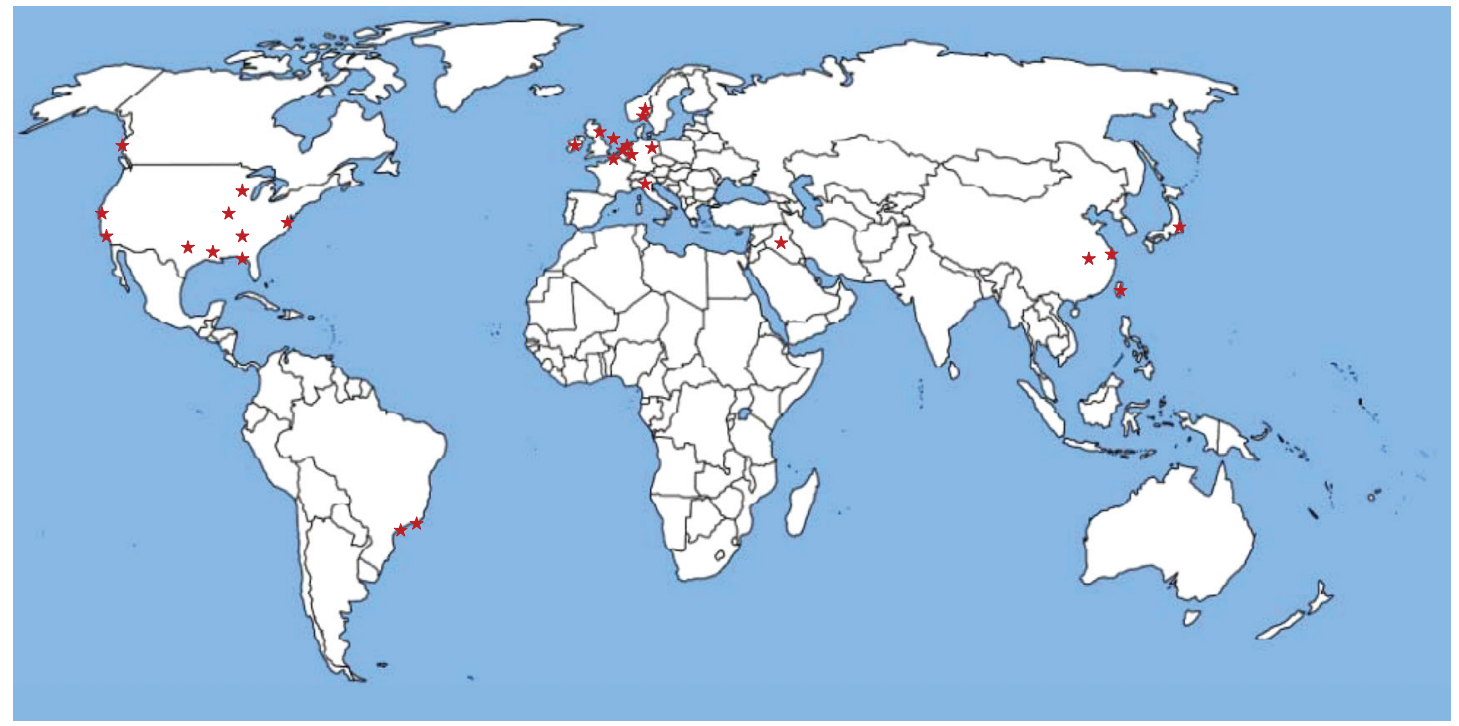

Fig. 1. Geographical distribution of ZJU-ICL database 
Table 4. Summary of statistics (mean $\mu \pm \mathrm{CoV}$ ) of API and CPT methods (pile age $=10-100 \mathrm{~d}$ )

\begin{tabular}{l|c|c|c|c|c|c|c}
\hline \multirow{2}{*}{ Database } & \multicolumn{2}{|c|}{ ICP-05 } & \multicolumn{2}{c|}{ UWA-05 } & \multirow{2}{*}{ Fugro-05 } & \multirow{2}{*}{ NGI-05 } & \multirow{2}{*}{ API } \\
\cline { 2 - 5 } & Full & Simplified & Full & Offshore & & & \\
\hline ICP & $0 \cdot 97 \pm 0 \cdot 35$ & $0 \cdot 69 \pm 0 \cdot 38$ & $1 \cdot 00 \pm 0 \cdot 32$ & $0 \cdot 84 \pm 0 \cdot 38$ & $1 \cdot 11 \pm 0 \cdot 41$ & $1 \cdot 16 \pm 0 \cdot 50$ & $0 \cdot 87 \pm 0 \cdot 66$ \\
UWA & $0 \cdot 96 \pm 0 \cdot 33$ & $0 \cdot 69 \pm 0 \cdot 37$ & $1 \cdot 00 \pm 0 \cdot 32$ & $0 \cdot 85 \pm 0 \cdot 38$ & $1 \cdot 12 \pm 0 \cdot 41$ & $1 \cdot 19 \pm 0 \cdot 49$ & $0 \cdot 87 \pm 0 \cdot 63$ \\
New ZJU-ICL data & $0 \cdot 96 \pm 0 \cdot 22$ & $0 \cdot 72 \pm 0 \cdot 30$ & $1 \cdot 12 \pm 0 \cdot 32$ & $0 \cdot 96 \pm 0 \cdot 41$ & $1 \cdot 32 \pm 0 \cdot 46$ & $1 \cdot 27 \pm 0 \cdot 44$ & $0 \cdot 93 \pm 0 \cdot 43$ \\
Total ZJU-ICL data & $0 \cdot 96 \pm 0 \cdot 28$ & $0 \cdot 70 \pm 0 \cdot 34$ & $1 \cdot 05 \pm 0 \cdot 32$ & $0 \cdot 90 \pm 0 \cdot 40$ & $1 \cdot 21 \pm 0 \cdot 45$ & $1 \cdot 23 \pm 0 \cdot 47$ & $0 \cdot 90 \pm 0 \cdot 55$ \\
\hline
\end{tabular}

remain to be made by the authors and other workers regarding axial capacity and stiffness behaviour. Here, only some broad checks are offered on the overall predictive performance of the Main Text API method and the four cited CPT-based approaches, considering for the UWA and ICP procedures both the 'full' versions and the 'offshore' and 'simplified' formulations listed by API RP2GEO. The latter procedures are included in the API GEO commentary section, but do not appear to have been tested systematically in earlier database studies. $Q_{\mathrm{c}} / Q_{\mathrm{m}}$ ratios were established for each database entry for the capacities calculated by each method and that measured. Simple arithmetic statistical means $(\mu)$ and CoVs are presented. Noting that some methods employ relative density $\left(D_{\mathrm{r}}\right)$ values for parts of their calculations, the latter were derived from the CPT $q_{\mathrm{c}}$ relationship given by Jamiolkowski et al. (2003)

$$
D_{\mathrm{r}}=0.35 \ln \left(q_{\mathrm{c} 1 \mathrm{~N}} / 20\right)
$$

where $q_{\mathrm{c} 1 \mathrm{~N}}=\left(q_{\mathrm{c}} / p_{\mathrm{A}}\right) /\left(\sigma_{\mathrm{v} 0}^{\prime} / p_{\mathrm{A}}\right)^{1 / 2}, p_{\mathrm{A}}=100 \mathrm{kPa}$.

The cases adopted from the ICP and UWA databases outlined above were recalculated to ensure that the calculations for each case are as consistent as possible, adopting more refined CPT $q_{\mathrm{c}}$ values and calculation resolution where possible. This step also provided a means of checking the results obtained and eliminating any errors.

Table 4 compares the preliminary statistical summary, listing mean and $\mathrm{CoV} Q_{\mathrm{c}} / Q_{\mathrm{m}}$ values of the API Main Text and CPT methods, considering the ICP, UWA, new ZJUICL data entries and the combined ZJU-ICL datasets. Inspecting the results obtained with seven methods and four databases shows the following broad trends.

- Broad agreement with the trends reported by Jardine et al. (2005) and Schneider et al. (2008).

- The 'simplified' ICP and 'offshore' UWA methods give lower mean values $\mu$ and larger CoVs than their 'full' versions. The authors suggest that there is no benefit in applying the simplified ICP approach in place of the full version as it gives an unnecessarily conservative $\mu$ and a larger CoV. However, the 'full' UWA version appears marginally non-conservative and the UWA 'offshore' method may be preferable, despite its higher CoV.

- The mean $Q_{\mathrm{d}} / Q_{\mathrm{m}}$ values range from 0.69 to 1.32 over all the cases covered and the CoVs from $0 \cdot 22$ to $0 \cdot 66$, with the Main Text API method giving consistently higher CoVs than the CPT approaches.

- The 'full' UWA and ICP methods give lower CoVs $(0 \cdot 22$ to $0 \cdot 35)$ than the other CPT approaches $(0 \cdot 41$ to $0 \cdot 50)$ and mean $Q_{\mathrm{d}} / Q_{\mathrm{m}}$ values close to unity.

\section{SUMMARY AND CONCLUSIONS}

This paper reviews the background for developing highquality pile test databases and shows that there is a critical need to develop such resources for driven piles. The characteristics of two leading datasets were considered before outlining the Zhejiang University/Imperial College London (ZJU-ICL) database, reporting how it was assembled and describing how it may be accessed by other workers. The paper also sets out the key quality parameters adopted, the population of current entries and the reporting format. Preliminary results obtained from comparisons of axial capacities calculated by various approaches and site measurements confirm key points identified in earlier ICP and UWA studies.

- The existing Main Text API procedures are subject to far larger predictive $\mathrm{CoVs}$ than the alternative CPT methods.

- The UWA and ICP procedures appear to offer the least scatter and little bias in predictions for the axial capacities of the piles included in the current ZJU-ICL database.

A new point to emerge is that the 'simplified' ICP variant is over-conservative in the cases considered. It is thus recommend that future onshore and offshore applications should adopt the 'full' formulation set out by Jardine et al. (2005), as in the multiple offshore projects reported by Overy (2007).

The new database adds significantly (by 90\%) to the population of high-quality pile load tests that meet the criteria set to test capacity and stiffness design methods. This resource offers scope for evaluating potential prediction biases relating to a wide range of soil and pile parameters. Colleagues are encouraged to consider submitting further high-quality tests for inclusion into the database so that the value of this freely accessible research resource can continue to grow.

\section{APPENDIX}

See Figure A.1 for an example of one data entry in the ZJU-ICL database, which will be released with a webbased version and in print.

\section{ACKNOWLEDGEMENTS}

The ZJU-ICL database project is funded by the Natural Science Foundation of China (grants 51178421 and 51322809) and the Chinese Ministry of Education Distinguished Overseas Professorship Programme. The authors also acknowledge support from the National Key Basic Research Program of China (SQ2015CB070563), Zhejiang University K. P. Chao's High Technology Development Foundation and the Fundamental Research Fund for Central Universities (2014XZZX003-15). We would also like to thank many research groups for providing data, particularly Prof. Rücker of the Federal Institute for Materials Research and Testing in Germany, Dr Tsuha from the University of São Paulo at São Carlos in Brazil, Prof. Mayne and Dr Niazi from Georgia Tech in the USA, and Prof. Frank and Dr Burlon from IFSTTAR in France. 
Site ID No. 3: K27, Wuhu, China

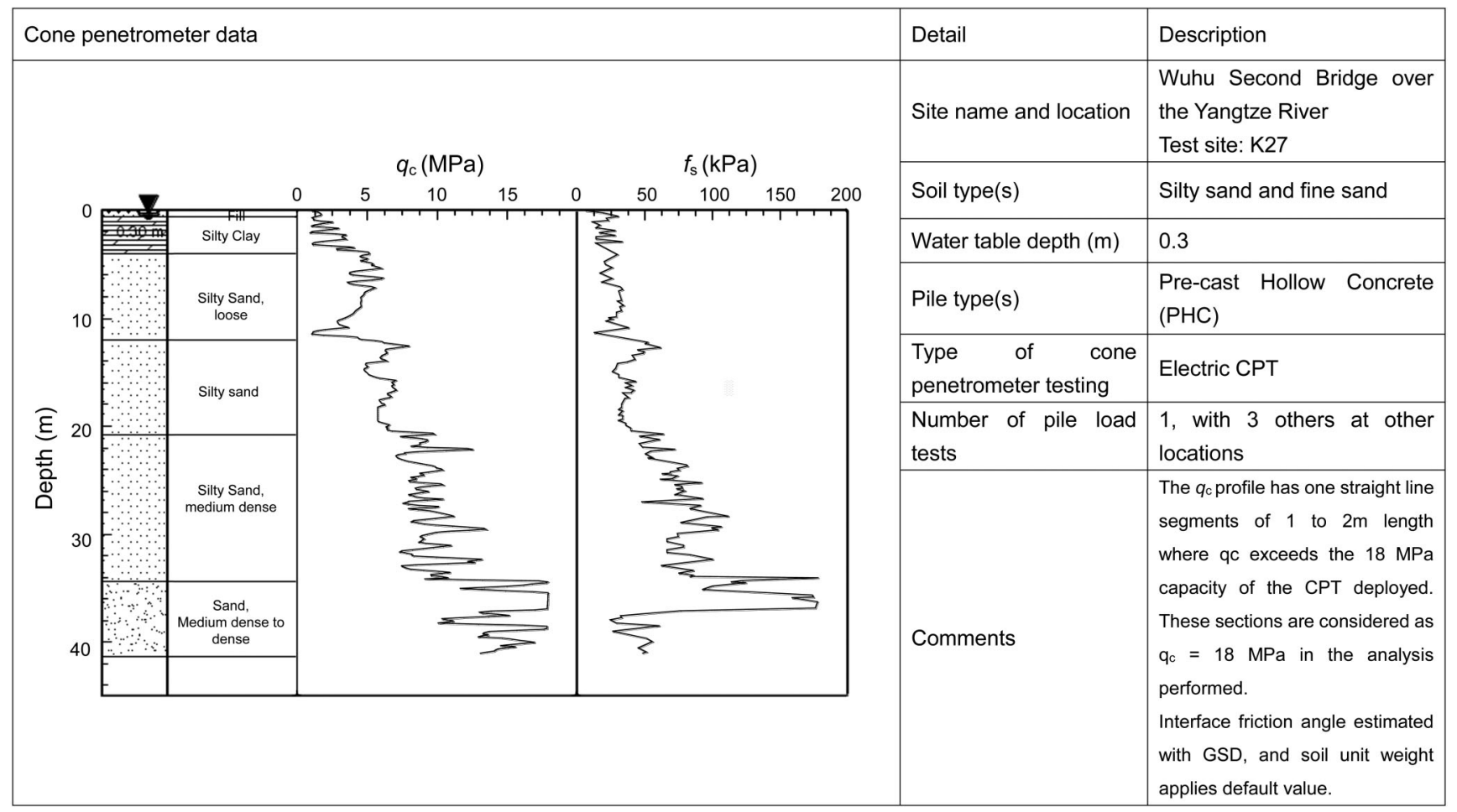

Pile ID: Wuhu K27-1

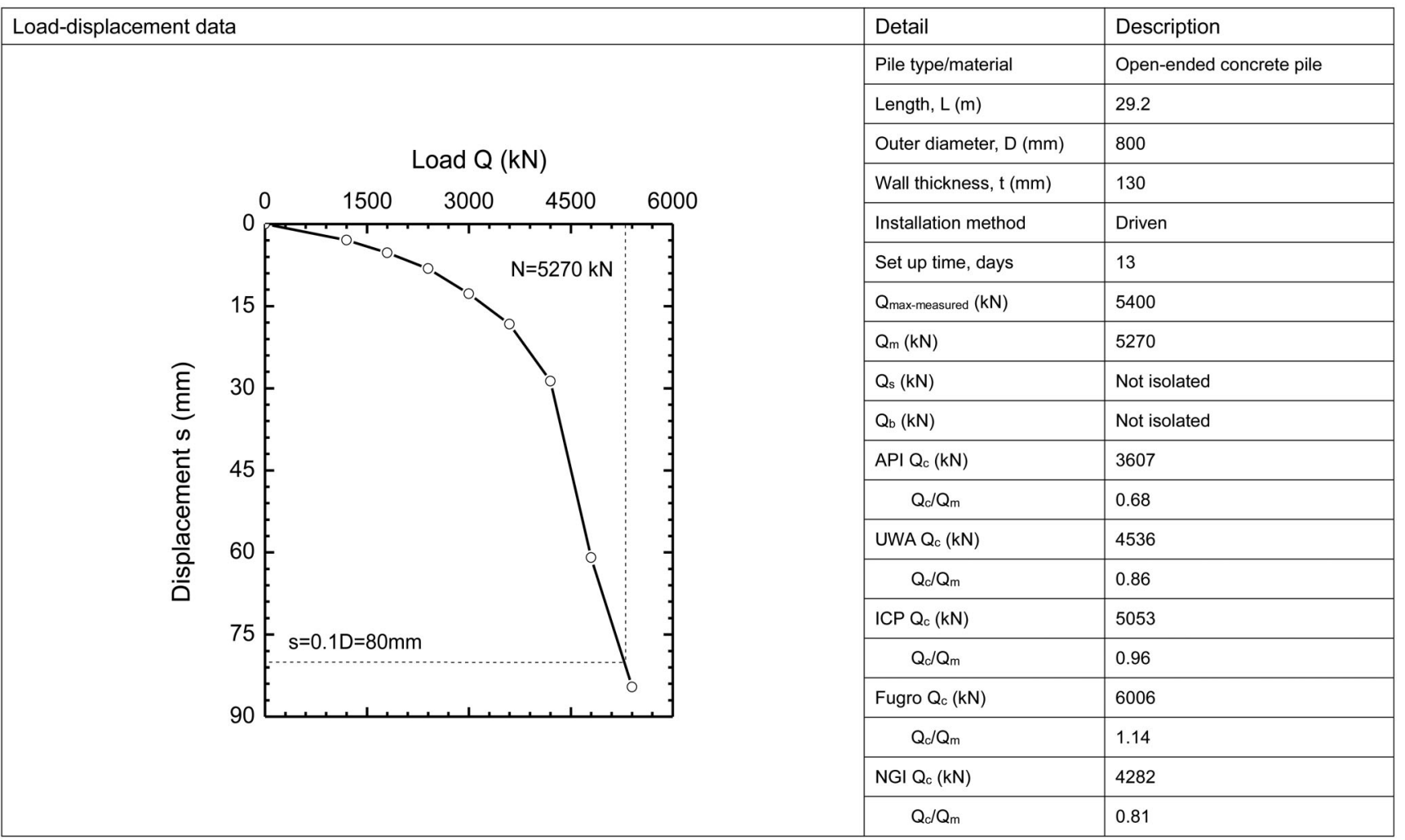

Fig. A.1. An example description of test site and pile load test (Yang et al., 2015)

\section{REFERENCES}

API (American Petroleum Institute) (2014). ANSI/API recommended practice $2 G E O$, 1st edn, RP2GEO. Washington, DC: API.

Briaud, J. L. \& Tucker, L. M. (1988). Measured and predicted axial response of 98 piles. J. Geotech. Engng 114, No. 9, 984 1001 .
Chow, F. C. (1997). Investigations into displacement pile behaviour for offshore foundations. $\mathrm{PhD}$ thesis, Imperial College London, UK.

Clausen, C. J. F., Aas, P. M. \& Karlsrud, K. (2005). Bearing capacity of driven piles in sand, the NGI approach. Proc. Int. Symp. on Frontiers in Offshore Geotechnics. London: Taylor \& Francis, pp. 677-681. 
de Gijt, J. G., van Dalen, J. H. \& Middendorp, P. (1995). Comparison of statnamic load test and static load tests at the Rotterdam Harbour. Proc. 1st Int. Statnamic Seminar, Vancouver, 27-30 September, $11 \mathrm{pp}$.

Gavin, K. G., Igoe, D. J. P. \& Kirwan, L. (2013). The effect of ageing on the axial capacity of piles in sand. Proc. Inst. Civ. Eng. - Geotech. Engng 166, No. 2, 122-130.

Hölscher, P. (2009). Field test rapid load testing Waddinxveen. The Netherlands: Deltares, $95 \mathrm{pp}$.

Jamiolkowski, M. B., Lo Presti, D. F. C. \& Manassero, M. (2003). Evaluation of relative density and shear strength of sands from cone penetration test. Soil behaviour and soft ground construction. Reston, VA: ASCE, Geotechnical special publication 119, pp. 201-238.

Jardine, R. J. (2013). Advanced laboratory testing in research and practice. Second Bishop Lecture, Proc. 18th Int. Conf. on Soil Mechanics and Geotechnical Engineering. Paris: Presses des Ponts, pp. 25-55.

Jardine, R. J., Chow, F. C. \& Overy, R. (2005). ICP design methods for driven piles in sands and clays. London: Thomas Telford.

Jardine, R. J., Standing, J. R. \& Chow, F. C. (2006). Some observations of the effects of time on the capacity of piles driven in sand. Géotechnique 56, No. 4, 227-244.

Jardine, R. J., Zhu, B. T., Foray, P. \& Dalton, C. P. (2009). Experimental arrangements for investigation of soil stresses developed around a displacement pile. Soils and Found. 49, No. $5,661-673$.

Jardine, R. J., Zhu, B. T., Foray, P. \& Yang, Z. X. (2013a). Measurement of stresses around closed-ended displacement piles in sand. Géotechnique 63, No. 1, 1-17.

Jardine, R. J., Zhu, B. T., Foray, P. \& Yang, Z. X. (2013b). Interpretation of stress measurements made around closedended displacement piles in sand. Géotechnique 63, No. 8, 613627.

Karlsrud, K., Jensen, T. G., Wensaas Lied, E. K., Nowacki, F. \& Simonsen, A. S. (2014). Significant ageing effects for axially loaded piles in sand and clay verified by new field load tests. Offshore Technology Conf., Houston, doi:10.4043/25197-MS.

Kolk, H. J., Baaijens, A. E. \& Sender, M. (2005). Design criteria for pipe piles in silica sands. Proc. Int. Symp. on Frontiers in Offshore Geotechnics. London: Taylor \& Francis, pp. 711-716.

Komurka, V. E. \& Grauvogl-Graham, J. L. (2010). Pile test program report: Lafayette Bridge Replacement. Report No. 09019 submitted to Minnesota Department of Transportation, by Wagner Komurka Geotechnical Group, Inc., Cedarburg, WI: $844 \mathrm{pp}$.

Lehane, B. M. \& Jardine, R. J. (1994). Shaft capacity of driven piles in sand: a new design approach. Proc. VII Int. Conf. on Behaviour of Offshore Structures, Boston, 1, 23-36.

Lehane, B. M., Jardine, R. J., Bond, A. J. \& Frank, R. (1993). Mechanisms of shaft friction in sand from instrumented pile tests. J. Geotech. Engng Div. ASCE 119, No. 1, 19-35.

Lehane, B. M., Schneider, J. A. \& Xu, X. (2005). A review of design methods for offshore driven piles in siliceous sand. Perth: University of Western Australia, UWA Report GEO 05358.

Mayne, P. W. \& Elhakim, A. (2002). Axial pile response evaluation by geophysical piezocone tests. Proc. 9th Int.
Conf. on Piling and Deep Foundations, DFI, Nice: Presses de l'ecole nationale des Ponts et Chausses, pp. 543-550.

Merritt, A., Schroeder, F., Jardine, R. J. et al. (2012). Development of pile design methodology for an offshore wind farm in the North Sea. Proc. 7th Offshore Site Investigation and Geotechnics: Integrated Geotechnologies - Present and Future. London: SUT, pp. 439-447.

Naesgaard, E., Amini, A., Uthayakumar, U. M. \& Fellenius, B. H. (2012). Long piles in thick lacustrine and deltaic deposits. Two bridge foundation case histories. Reston, VA: ASCE, Geotechnical special publication 227, pp. 404-421.

Niazi, F. S. (2014). Static axial pile foundation response using seismic piezocone data. $\mathrm{PhD}$ thesis, Georgia Institute of Technology, Atlanta, GA

Overy, R. (2007). The use of ICP design methods for the foundations of nine platforms installed in the U.K. North Sea. Proc. 6th Int. Conf. on Offshore Site Investigations and Geotechnics. London: Society for Underwater Technology, 8 $\mathrm{pp}$

Pando, M., Filz, G., Ealy, C. \& Hoppe, E. (2003). Axial and lateral load performance of two composite piles and one prestressed concrete pile. Proc. TRB 2003 Annual Meeting.

Rücker, W., Karabeliov, K., Cuéllar, P., Baeßler, M. \& Georgi, S. (2013). Großversuche an Rammpfählen zur Ermittlung der Tragfähigkeit unter zyklischer Belastung und Standzeit. Geotechnik 36, No. 2, 77-89.

Schneider, J. A., Xu, X. \& Lehane, B. M. (2008). Database assessment of CPT-based design methods for axial capacity of driven piles in siliceous sands. J. Geotech. Geoenviron. Engng ASCE 134, No. 9, 1227-1244.

Tsuha, C. H. C., Foray, P. Y., Jardine, R. J. et al. (2012). Behaviour of displacement piles in sand under cyclic axial loading. Soils and Found. 52, No. 3, 393-410.

White, D. J. \& Lehane, B. M. (2004). Friction fatigue on displacement piles in sand. Géotechnique 54, No. 10, 645-658.

Williams, R. E. Chow, F. C. \& Jardine, R. J. (1997). Unexpected behaviour of large diameter tubular steel piles. Proc. Int. Conf. on Foundation Failures. Singapore: IES, NTU, NUS and Institute of Structural Engineers, pp. 363-378.

$\mathrm{Xu}, \mathrm{X}$. (2006). Investigation of the end bearing performance of displacement piles in sand. $\mathrm{PhD}$ dissertation, University of Western Australia, Perth.

Yang, Z. X., Jardine, R. J., Zhu, B. T., Foray, P. \& Tsuha, C. H. C. (2010). Sand grain crushing and interface shearing during displacement pile installation in sand. Géotechnique 60, No. 6, $469-482$.

Yang, Z. X., Jardine, R. J., Zhu, B. T. \& Rimoy, S. (2014). Stresses developed around displacement piles penetration in sand. J. Geotech. Geoenviron. Engng ASCE 140, No. 3, http:// dx.doi.org/10.1061/(ASCE)GT.1943-5606.0001022.

Yang, Z. X., Guo, W. B., Zha, F. S. et al. (2015). Field behaviour of driven Pre-stressed High-strength Concrete piles in sandy soils. J. Geotech. Geoenviron. Engng ASCE, doi:10.1061/ (ASCE)GT.1943-5606.0001303.

Zhang, C., Yang, Z. X., Nguyen, G. D., Jardine, R. J. \& Einav, I. (2014). Theoretical breakage mechanics and experimental assessment of stresses surrounding piles penetrating into dense silica sand. Géotech. Lett. 4, January-March, 11-16.

\section{WHAT DO YOU THINK?}

To discuss this paper, please email up to 500 words to the editor at journals@ice.org.uk. Your contribution will be forwarded to the author(s) for a reply and, if considered appropriate by the editorial panel, will be published as a discussion. 